Afrika Focus, Vol. 9, Nr. 1-2, 1993, pp.43-72

\title{
LOCAL RULERS IN NORTH CAMEROON THE INTERPLAY OF POLITICS AND CONVERSION
}

\section{Kees SCHILDER}

African Studies Centre, P.O. Box 9555, 2300 RB Leiden, Netherlands.

\section{SUMMARY}

This article analyses the conversion to Islam of indigenous chiefs in North Cameroon. The chiefs studied belong to the Mundang ethnic group. Their islamisation is interpreted as the outcome of the ambivalence brought about by their intermediary role between local society and the wider society. This approach offers insights in (a) the connection between conversion and political careers; (b) the relation between Islam and ethnic identities; and (c) the popular legitimacy of conversion.

KEY WORDS: Cameroon, Mundang, chiefs, Islam, ethnicity, cosmology

\section{Introduction}

Most theoretical thinking on ethnicity in sub-Saharan Africa is based on ethnographic cases in southern Africa. Ethnic processes in the Muslim societies of Africa are a relatively neglected field of study, especially the theoretical reflection on the relation between Islam and processes of ethnic identity formation and dissociation. A notable exception is Cohen's study on Hausa traders in Ibadan (in 
Nigeria) (1). Scholars of Islam in West Africa have generally stressed the alleged universalist influence of Islam, and have neglected its potential for particularism. However, the latter force is very important in order to understand the ethnic overtones Islam has acquired in many societies. Guy Nicolas is one of the few scholars who have paid attention to this phenomenon. He introduced the concept of the 'ethnicisation of Islam' or the 'ethnic rooting of Islam' (2). Although he does not explicitly define this notion, it contains a useful insight: an analytical distinction between religious and ethnic identities. The concept refers to the identification of an ethnic group with Islam to such a degree that this world religion becomes a central ethnic marker vis-à-vis other ethnic groups. This overlap of religious and ethnic identities is, however, never complete.

'Ethnicisation' of Islam is clearly present among the Fulbe of North Cameroon. It has become a central ethnic symbol for Fulbe-hood. Ethnic and religious identity have become so blurred in practice that Pullo (the singular form of the plural Fulbe) and Muslim are often regarded as synonyms in the region. Conversion to Islam of members of other ethnic groups in the region has generally been a prelude to assimilation into Fulbe society. As a result, the Fulbe have grown from a numerically small ethnic group into the largest one of the region over the past two centuries. This process of 'Fulbe-isation' has been well described by Schultz for the town of Guider in North Cameroon (3). Since the late colonial period, however, a new pattern has emerged: religious and ethnic identity changes are no longer inextricably interwoven; often, converted people do no longer change their ethnic identity, and continue to strongly participate in their ethnic group of origin.

In this paper I focus on the islamisation of the royal chiefs of one of the indigenous ethnic groups in North Cameroon, in order to illustrate ethnic-religious developments of this nature. The ethnic group in question is called the Mundang. They are one of the many ethnic groups in the area; the Fulbe have generally labelled these groups Haabe, 'Pagans', i.e. a category of despised non-Muslims who lack any civilization (4). The Mundang partly live in Cameroon and partly on the other side of the border in Chad (see map). The northern Mundang, among whom I did anthropological field-work in 1988-1990 and 1992, live in the central zone of the Kaele Prefecture, in the south-eastern part of the Extreme North Province of Cameroon (5). The Cameroonian Mundang are a rather small group - they make up less than $1 \%$ of the total population of the country. They consider themselves to be offshoots from the Chadian Mundang; the latter's homeland, with Lere as its capital, is seen as the Mundang heartland. The history of the group goes back to at least the middle of the eighteenth century. Politically, their society is characterised by a number of kingdoms or chieftaincies into which the pre-existing kinship-based clan organization has been integrated (6). 
In order to grasp the social significance of the conversions to Islam of several Mundang kings, two contextual factors need to be brought into the argument. I think the islamising chiefs are caught in between (a) a certain degree of hegemony of the Fulbe in the wider society (external power relations), and (b) the demands and aspirations of the common Mundang population (internal power relations). My hypothesis is that these two factors have limited the chiefs's freedom of manoeuvre. Without any doubt my analytic approach is not exhaustive: other internal tensions than those between the chiefs and the common population have also played a part in the process, e.g. the collective memory of frictions with the Fulbe in the 19th century.

After a description of the historical background and of the process of islamisation of the two chiefs involved, I shall first focus upon the external power relations: the political career ambitions of the chiefs in the context of the formation of a regional power bloc at the eve of independence. Then the internal power relations will be dealt with, and I shall complete the article with conclusions concerning the cosmological dimension of conversion and ethnicity.

\section{Historical background}

Islam has managed to spread into the West African savannah societies since about the eleventh century $\mathrm{AD}$. The first to convert were generally the kings. The growing influence of Muslim scholars and traders at the court centres of the Bambara, Serer, Kotoko, Mandara, Hausa and other states is rather well documented, as is the limited impact of this religion at these courts. Many chiefs developed a kind of syncretic version of Islam, as they usually continued to be attached to pre-Islamic political, juridical and ritual practices of governance which were not easily reconcilable with orthodox Islam. To these rulers the Muslim religion was a supplementary source of power, as it gave them access to the profitable trade circuits which extended into the Arab world at the other side of the Sahara desert (7).

Since the eleventh century $\mathrm{AD}$, Islam has also slowly penetrated into the area that is nowadays called North Cameroon. This centuries-old process accelerated in the first half of the 19th century, when the Fulbe established a large empire in northern Nigeria, which also incorporated the region under investigation. This state-building process, born out of a 'holy war' movement, has resulted - after the forces of fission had done their work - in a number of Fulbe states, which are called lamidates. 


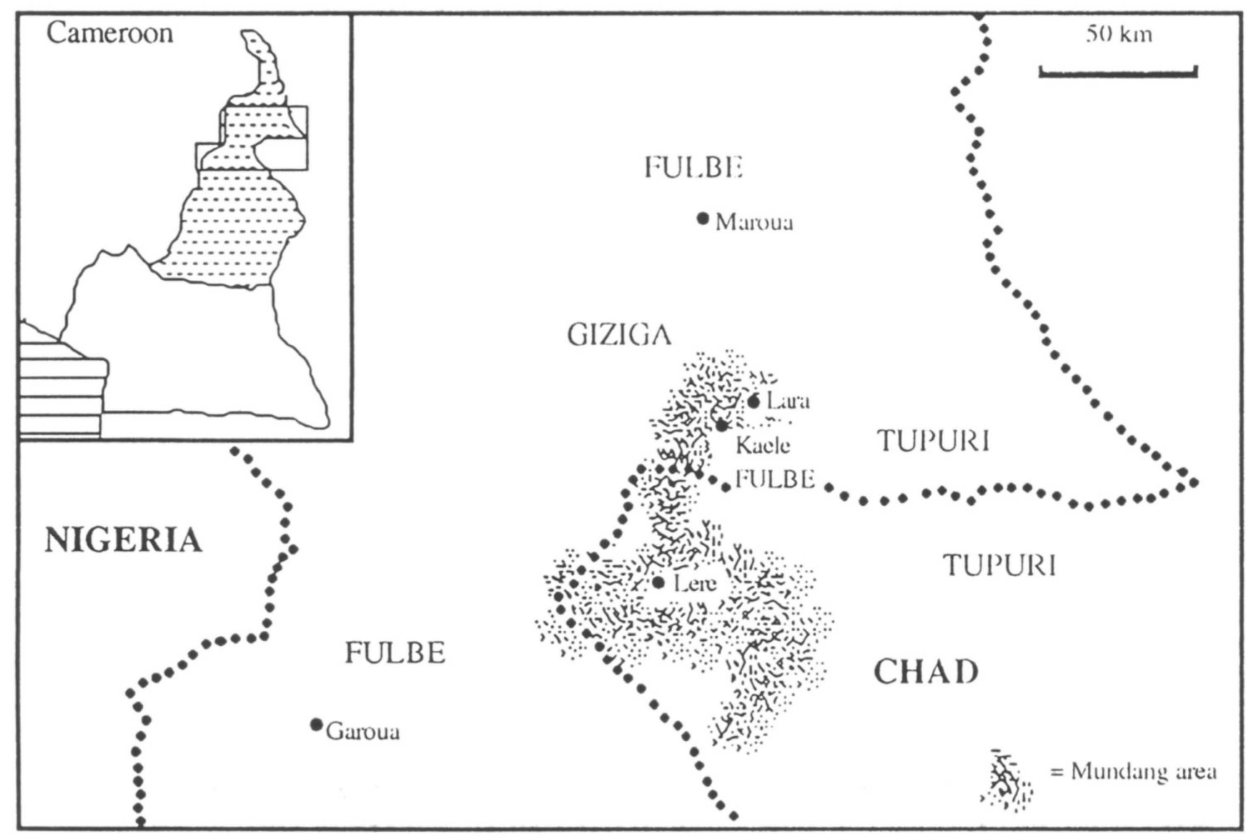

Diagram 1: The Mundang area in North Cameroon 
Most autochthonous ethnic groups became more or less subjugated to these states in the 19th century. The Fulbe raiders were not only interested in territorial expansion, but also, and especially, in making slaves. The northern Mundang have probably suffered a great deal because of the regular attacks of the powerful and prestigious Fulbe enemies, but they have always succeeded in maintaining a considerable degree of autonomy. The Mundang kings, whose spheres of influence were usually limited to a relatively small number of nearby villages, were the main organizers of opposition. This pattern of violent interaction in the periphery of the Fulbe lamidates has hardened the ethnic boundary between Fulbe and Mundang, although more peaceful interaction patterns, commercial relations notably, were far from absent. The colonial powers - first Germany and then France - have consolidated the ethnic gap which had emerged in the 19th century: as from the 1920 s, the Mundang kingdoms were administratively separated from the lamidates that had claimed hegemony over them (8).

The 'ethnicisation of Islam' is very apparent in the Fulbe society of North Cameroon. The invasions, conquests and subsequent state formation were legitimated by means of Islam, which thus particularised into a state religion and political ideology. In this situation Islam has become the main instrument for the articulation of ethnic boundaries. Mundang local culture has developed an ambiguous attitude towards Islam. On the one hand, it is seen as the religion of the conquering ethnic group of the past, and the cornerstone of a superior culture; but on the other hand, it is regarded as the religion of a (formerly) aggressive enemy, which must be rejected. This Mundang ambivalence exemplifies a central feature of the ethnic hierarchy which emerged in the region: a bias toward political autonomy, combined with an acceptance of cultural inferiority. The Fulbe used the generic term Kaado (pl. Haabe), 'Pagan', to designate the status of potential slaves which they accorded to the Mundang and other indigenous groups.

\section{Conversion to Islam}

Penetration of Islam into local Mundang society is a very recent phenomenon: it only started after World War II. This is not to say that islamisation was completely absent before, but rather that individual conversions took place in a social context of integration into the wider, Fulbe-dominated society. This integration inevitably ended up in ethnic identity change: islamised Mundang eventually became Fulbe. The first converts who broke this pattern and remained full members of local Mundang society, were the chiefs. This conforms to the general pattern, as described above, of diffusion of West African Islam: it are usually the chiefs who 
are the first to convert. Nowadays all three Mundang chiefs are Muslims. Zuah, the chief of Lara, who ruled from 1932 until 1979, was the first chief to convert. He had already become interested in Islam in the late $1930 \mathrm{~s}$, but it was only in 1948 that he actually converted, at the age of 42. The present chief of Lara, Ahmadu, told me a legend about this conversion of his father.

Muslims from Lere [the capital of the Mundang heartland] visited chief Zuah in Lera, a village near Lara and the old capital of the kingdom. When they withdrew for the prayer ritual, Zuah decided to test their piety. He took an old German rifle and loaded it with three cartridges. When he tried to fire in order to get them out of their concentration, the weapon refused, no matter how much he tried. When the Muslims had finished their prayer, he tried again, and this time he succeeded. This miracle convinced him of the power and glory of the God of the Muslims, and made him decide to convert. He was the first Mundang of Lara to become a Muslim, through the intervention of Mustapha, a Muslim scholar, who was sent by the emir of Yola.

Initially Zuah only adopted the outward appearances of Islam, but after some years he became more devout. In 1955 he raised his Muslim status by making the pilgrimage to Mecca, so that after his return he could adorn himself with the prestigious title of alhadji (Fulfulde; Arab.: hadjdj). In 1966 he made the journey to Mecca again. By that time he had already started to use his Muslim name, Ahmadu, in public.

Chief Kakiang of the kingdom of Kaele was the second chief to convert. He became a Muslim in 1955, in the year that he was also appointed as chief of Kaele, at the age of 25 . In the 1940s he had attended a primary school of the Lutheran Mission in the area, and had been interested in Christianity for some time; he even adopted a self-chosen francophone Christian name. After his conversion to Islam he revealed himself more and more as a very strict Muslim, and started to call himself Abubakar. In 1966 he became a hadjdj, after having accomplished the Mecca pilgrimage. Both chiefs strictly observed the fasting rules of the Ramadan month, probably because these tend to function as a major social marker of Muslim-hood, and thus as an outward 'sign' of a person's Muslim identity.

Islam presented itself to these Mundang chiefs in its Fulbe version. The ritual which accompanied chief Zuah's conversion, for example, was performed by a Fulbe Qur'anic scholar, according to the above legend. This is also clear from the mosque, which is a Fulbe modelled institution in local society: the architecture of the mosque in Kaele town is borrowed from the Fulbe, the sermon is in Fulfulde 
(the Fulbe's mother tongue), and the imam claims to be a Pullo being trained in religious matters in the Fulbe context.

As the Islam of the Fulbe has become strongly ethnicised, one would expect that islamisation would go together with an adoption of other aspects of the Fulbe culture. This has indeed been the case. The two chiefs transgressed the Mundang prohibition on ethnic exogamy with the Fulbe, and were thus able to establish a Muslim household in their palace. Both married several Fulbe women (besides a large number of Mundang women). Zuah's religious zeal was at its height after his return from Mecca in 1955: he sent away his many spouses, except for four of them (which conforms to the officially admitted maximum number according to Islamic law). His devoutness did not last though: after a few years he took back most of his former wives as 'concubines'. Chief Kakiang married four Fulbe women; they all originate from neighbouring Fulbe villages.

The chiefs demanded that an intended wife would convert to Islam (if she had not done so already) and adopt a Muslim name. In their households - where Islam has tended to obscure the members's differences in ethnic backgrounds - Fulbe influences have become manifest. This is clear from the names of the members, the use of Fulfulde as the major domestic language, and the application of the rule of female seclusion. The chiefs also have taken care that their numerous offspring would acquire some years of Muslim education.

\section{Adoption of Fulbe court culture}

The adoption of Fulbe cultural elements has been even more pronounced in the political domain. This corroborates the idea that Islam has functioned as a political ideology in Fulbe society (9). Both rulers identified with the Fulbe kings (laamiibe, sing. laamiido) in North Cameroon and adopted Fulbe regalia. This is most manifest in the way they started to present themselves at official occasions in a kind of ceremonial procession: the chief would sit on a horse, dressed in the Fulbe way, his head protected by a sunshade. He would be preceded by horsemen announcing the royal arrival with drums and flutes, and would be followed by his notables who were all dressed in boubous.

Chief Zuah's invitation of a Qur'anic scholar from Yola is an indication that he tried to mobilize the old institution of the Yola emirate, that had been the superior, Fulbe political authority in North Cameroon in pre-colonial days. This impression is further confirmed by Zuah's request to the emir to be officially installed as a 
laamiido a few years later, in 1950. The favour was granted, so that he became the first indigenous chief in the area who was officially installed as laamiido by a Muslim superior ruler (instead of by the colonial power). He thus clearly made an attempt to become accepted by the Fulbe aristocracy as a legitimate Muslim chief (10).

Chief Kakiang's identification with the Fulbe rulers of the region has been even more pronounced. This is, for example, manifest in a poem composed by his orders in the late 1950s. This hymn is a fine illustration of the fact that he not only intended to emulate the actual behaviour of the distinguished Fulbe rulers, but also tried to conform to the old ideal image of the laamiido as it is present in Fulbe cosmology. The song, written in Fulfulde, was collected, translated into French, and published by Pierre-Francis Lacroix (11). I quote several lines (my translation; line numbers of the original appear between brackets):

The grand Deputy, our laamiido of Kaele, who commands in 'France' the whole of Kaele [9].

Father of Prince Ahmadu, I thank you. Prince Ahmadu is also a son of the Sultan [13].

Prince Buba, worthy of the throne and inseparable of the majesty, the world has seen it [16].

Buba, Prince of richness, son of the laamiido, the whole world agrees: Buba is generous [17].

Fadimatu, Lady who has an Arab appearance, Lady of all women: she is pretty [20].

Lady-companion, the Lady Aïssatu, I saw she looks like an Arab woman [24].

I switch to your courtiers, Laamiido, You, Deputy of our world, Distinguished One [25].

Honoured among the notables, You, the Favoured, Bubakari Garba, who is called the Distinguished One [27].

Undeniably, he is the treasurer. This treasure, I saw, contains money, not textiles [28].

Kaygamma, courtier of the laamiido of Kaele, his advice is accurate, and his words are well-spoken [30].

Beds and mattresses are, as I saw, stitched with gold. In the interior of the house it smells of perfume, it is delicious [35].

He opened his treasury, I had to turn my head away. The one who hides in your shade, does not live in poverty [39].

He built a house with a hundred doors; $a$ White man told me so, and this is not idle talk [40]. 
He has a company of soldiers as if it were a feast. They are a thousand, I counted them at a meeting [41].

Some are guards, others gendarmes; a French military man has become like His kaygamma [42].

Royal drums made of gold of our laamiido of 'France', You, who, as I noticed, is endowed with generosity and political sense [43].

Golden house, golden flag, beautiful like gold that shines like a pearl [44].

His house has surprised me, I took it for clouds, this house of our grand laamiido of Kaele [47].

The chief is called a laamiido, and like all laamiibe, he is supposed to be extra-ordinary rich: he possesses a treasury filled with money, and a sumptuous palace, where gold shines everywhere. This richness is one of the manifestations of divine grace, and thus a legitimation of Fulbe royal authority as divinely endowed. The Fulfulde word for majesty, laamu, is explicitly applied to one of Kakiang's sons, Buba. The princes are referred to with the Fulfulde word yeriima. The chief possesses one of the old regalia of the Fulbe rulers: the flag, which in pre-colonial times was given to a new ruler by the emir of Yola as a sign of instalment. Kakiang is presented as being wise, just and generous; this is all connected to a laamiido's responsibility for the rendering of justice and poor-relief.

The four central social categories of the Fulbe court are mentioned: the princes, the notables, the wives and the servants. Most persons mentioned have Islamic names. The Fulbe wives of the chief receive special attention. They are presented as Arab women. This association refers (a) to the close bond between Islam and the Arab ethnic identity, and (b) to a physical aspect of the ethnic distinction between Pullo and Pagan. A light skin is an indication of Fulbe-hood: the lighter the skin, the stronger the claim to this identity, as it counts as an outward sign of no or minimal mixing with the indigenous population. The Mundang name for the Fulbe, zemay, is related to this: it is associated with the colour bronze.

The military aspect of the court is not forgotten. The glorification of military power - a reminder of the Fulbe state-building in the early 19th century by conquer - brings the poet to even include the local police-force into the escort of the king to replace the old soldier-slaves. This is of course an inversion of the actual reality, as in the late colonial period the military power of the 'traditional' chiefs had already been reduced to zero point zero. 


\section{Political career ambitions}

The Mundang area has only been very marginally linked to the Muslim trade circuits in West Africa. Commercial ambitions could thus not have been the reason for the chiefly conversions. However, the desire to get access to the outside, Fulbe-dominated society was significant in this case too. Both chiefs have tried to set themselves up as the official representative and spokesman of the general Mundang population.

Chief Zuah was the first Mundang chief to become interested in national political issues. Due to an extension of the electoral suffrage for the Parliament in Yaounde two candidates could be recruited from the Kaele subdivision in 1952 . Three politicians had come from the South in order to create regional voting lists in North Cameroon under the banner of French political parties, in order to win local votes. The sub-divisional officer recommended that they choose Zuah as their local candidate, as the latter had proved to be the most active and loyal chief of the area. Zuah did not gain most of the votes - the other chiefs refused to support him out of fear that he would develop into a kind of super-chief. He was nevertheless chosen as a deputy, as two seats had been reserved for the Kaele district. However, he had to give up his parliamentary seat the next year, because he was considered not to be sufficiently qualified: he was illiterate and hardly spoke any French. A few years later, in 1955, Zuah made another attempt to put himself forward as the representative of the Mundang population, by trying to join a political initiative of the Fulbe ruler of Maroua, Yaya Dahiru: the Association Amicale des Musulmans du Diamaré (see below). He failed again because of the opposition of the other chiefs.

Chief Kakiang's political career is much more of a success-story. In 1956, just one year after his appointment as canton chief of Kaele, he was elected into the Parliament in Yaounde. His candidature was quite obvious, as at that time he was the only chief in the district with the required qualifications: he had attended primary school, and had some command of French. He made a lightning career. In 1958 he was chosen into the Central Committee (12) at the inaugural meeting of the Union Camerounaise (UC), which was to become the ruling party of Cameroon. Only in 1992 he had to give up this power position within the party, which is presently called Rassemblement Démocratique du Peuple Camerounais (RDPC). Until the introduction of a multi-party system in Cameroon in 1991, the Central Committee selected the candidates for the parliamentary seats, so that it was no problem for Kakiang to be re-elected in the National Assembly of 1960 and 
at the subsequent parliamentary elections (until 1988). For many years he was known as 'the deputy'. His political heydays were in the second half of the 1950s and in the 1960s, when he held special positions within Parliament, and when he was selected for several foreign trips (which are coveted prizes within the political patronage system). Since the early 1970s, his political influence has dropped: a new generation of politicians emerged in Cameroon, and a power struggle in Yaounde in the first half of the 1980s resulted in a considerable drop in power of politicians from North Cameroon.

Kakiang became the political representative of the southern part of the Diamare, an area that counted about 95.000 people in 1960 and presently about 160.000 . He was more or less a paramount chief who also represented the other ethnic groups in the area: the Giziga, the Tupuri, and even the few pockets of Fulbe. Within the Kaele district he was the main organizer and leader of the ruling party for several decades. In 1958, half a year after the creation of the Union Camerounaise party, a local cell was already created in Kaele town; in subsequent years other branches were established in the other chieftaincies of the region. Kakiang was the party president at the departmental level until 1982, and he is still one of its most prominent members.

\section{The northern power bloc, or the politicisation of ethnicity}

In order to grasp the relation between the conversions of the Mundang chiefs and their political career ambitions, we have to elaborate a little bit on the political context, because the decolonization of Cameroon in 1960-61 has had far-reaching consequences for the mode of governance of the state, and for the political career possibilities that came available. The first head of state of post-colonial Cameroon, Ahmadu Ahidjo, who came from the North, proved to be very skilful in handling the potential ethnic conflicts in the country. His political style was characterised by what might be called a system of ethnic proportionality or - to borrow a concept from Rothchild (13) - hegemonical exchange, in which political clientalism is the major stabilising factor. In francophone Cameroon it is known as the équilibre régional or the équilibre géopolitique. This means that the leaders of the many ethnic groups are co-opted by the national state elite: in return for their loyalty and cooperation, they receive a share in the resources of the state. The arena of exchange is not the Parliament - which was reformed into an institution of prebends in the 1960 s - but the unitary party. In 1966, the UC became the sole recognised political party in the country, after it had absorbed all the rival parties; 
this new position was marked by a change of name: UC became UNC (Union Nationale Camerounaise).

Ethnicity was used by the post-colonial state elite for incorporation purposes. The existing ethnic groups were politicised: they were transformed into the cornerstones of national politics, despite the official rhetoric against tribalism. This was largely due to the virtual absence of alternative mobilising forces for political group formation, like class. This is not to say of course that post-colonial politics in Cameroon is totally ethnicised: other loyalties and conflicts that run across ethnic lines do play their part.

This complex network of patron-client relations encompassed leaders of all ethnic groups in the country. For practical purposes these were lumped together to form a handful of ethnic regional clusters. Each political bloc is thus a coalition of several ethnic groups in one region. Until the early 1980 s, central state power was dominated by the Beti power bloc and especially the Northerners. After the presidential change in 1982 and a failed coup attempt in 1984, the Northern politicians lost most of their power. Since then the Beti have taken over most of the key positions. President Paul Biya - himself a Bulu, which is an ethnic group in the Central South, closely related to the Beti - has been much less successful than his predecessor in maintaining a balance of power between the ethnic-regional power blocs in the country. The multi-party parliamentary and presidential elections of 1992 made clear that the legitimacy of the Biya regime is presently seriously at stake, since its support in the north and especially in the west of the country turned out to be less than $50 \%$. The president is currently held responsible for the economic crisis in the country, as he is accused of having abused his powers to disproportionately favour members of his own ethnic group and region.

Let us now turn to the formation of the Northern power bloc in the late colonial period. The Fulbe have been the dominant ethnic group in this bloc. The leaders of the North became involved in national politics as a result of the establishment of a parliament with advisory powers by the French in the late 1940s. It were, however, not the leading laamiibe who came to dominate this bloc, but a new generation of young, Western-educated politicians, who generally were not closely related to the old Fulbe aristocracy. The rise of this new political elite in Fulbe society after the Second World War was not a smooth process. Most resistance came from the laamiido of Maroua, Yaya Dahiru. In 1955 he took the initiative to unite all Muslim chiefs in the Diamare for a common purpose - the establishment of a confederation after the example of the emirates in northern Nigeria, in order to safeguard a considerable degree of regional autonomy for the North in the approaching post-colonial state of Cameroon. This failed, and in 1959 
he was even forced to resign. Chief Zuah of Lara had evidently backed the wrong horse (or bull).

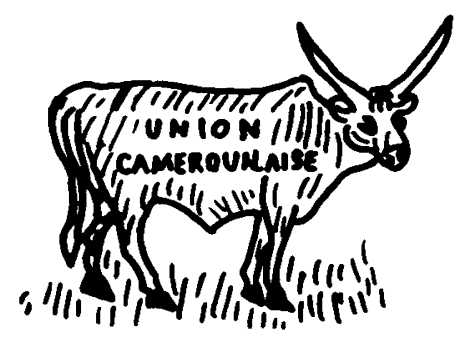

The Northern power bloc has been dominated by the Fulbe. This is, for example, evident in the official emblem of the UC party: a bull, which refers to the nomadic past of the Fulbe. However, the indigenous ethnic groups were not completely excluded from political power. The chiefs of these groups were integrated into the $\mathrm{U}(\mathrm{N}) \mathrm{C}$ party, which has had a virtual monopoly in the North since its establishment in 1958. In the Kaele area it was the chief of Kaele who became the party leader, whereas the other local chiefs were co-opted as presidents of the local party branches. They were rewarded with all kinds of favours and prerogatives, such as high salaries, government-sponsored cars, parliamentary seats, and a considerable freedom of political manoeuvre in the rural parts of their cantons.

The political relevance of the autochthonous ethnic groups in North Cameroon was thus explicitly recognised by the post-colonial regime. President Ahidjo probably realised that he could not consolidate his power in the North without the inclusion of the non-Fulbe ethnic groups into the political system. The power relations had gradually changed during the colonial period, due to several causes. The numerical dominance of the non-Fulbe groups had increased as a result of the relatively low fertility rates among the Fulbe. The same holds true for their political and economic impact. After World War II ethnic groups like the Mundang had taken advantage of the new opportunities which had come available in the form of cash crop production, Christianity, education, and general suffrage. The new Fulbe politicians were aware that these indigenous groups were no longer the marginalised Pagans that most Fulbe still held them to be.

Within the power bloc the dominant group, the Fulbe, has exerted cultural hegemony over the others. The royal elites of the incorporated groups have been 
forced to accommodate the Fulbe in the fields of language, religion, and political authority. The Fulbe have imposed not so much their name upon the new power bloc - it has a regional label - but rather their language, their religion, and their political culture. French is the official state language in North Cameroon, but it is Fulfulde which prevails in the informal political circuits; Zuah and Kakiang did not have any language communication problem, as both had a command of Fulfulde. The cultural interaction problem between the autochthonous chiefs and the Fulbe leaders was solved by a hegemonic demand of conversion to Islam and adoption of Fulbe royal symbolism: only non-Fulbe chiefs who were willing to adopt this religion, and to adopt the outward characteristics of 'traditional' Fulbe authority, were acceptable as political partners to the Fulbe elites. The effect was that political power in North Cameroon came to be effectively monopolised during the 1960s and 1970s by Fulfulde speaking Muslims, be they Fulbe or not.

The two Mundang chiefs have given in to these hegemonic demands: they have displayed a very direct type of reference group behaviour. A co-opted chief like Zuah tried to enhance his power and prestige, and to become a leading politician in the Northern power bloc. Unfortunately for him, the Fulbe rulers in the Diamare generally refused to acknowledge Zuah as a $100 \%$ Muslim chief - they saw him as a 'Pagan Muslim', as a Muslim of dubious reputation who had not yet completely shed his Pagan past - notwithstanding his official instalment as a laamiido by the emir of Yola.

Chief Kakiang has been more successful, as he managed to become one of the leading politicians of the Northern power bloc. His frantic efforts to give his Mundang kingship a new authority that was acceptable to the Fulbe elites in the North should be seen in this light. In the regional prestige system of royal authority, Fulbe 'traditional' leadership was used as the standard of prestige, and Kakiang wished to rise on this prestige scale by means of mimetic behaviour. But he too has never managed to completely distance himself from his former Pagan identity. The above mentioned poem contains several clues to his ambivalent status in Fulbe circles.

First, Kakiang could not find a first-class Fulbe poet to make the hymn. It was not written by one of the outstanding poets of this kind of literature, who are without exception of Fulbe aristocratic origins. The ethnic identity of the writer, Buuba Malum Jariida, was rather ambivalent, as he was the son of a Bornu man and a Hausa woman. In Fulbe literate circles he was considered as a second-rate poet, somewhere in between the most prestigious poets and the griots (14). 
Secondly, Kakiang did not have any religious authority: he had hardly received Islamic instruction, and he was not affiliated to a Muslim brotherhood. Therefore it is no surprise that the essential role of a laamiido as the moral guide and protector of the local Muslim community that God has dedicated to him, is hardly mentioned in the song.

Thirdly, the poem keeps silent about the descent of Kakiang, which contradicts to the Fulbe custom to make much of royal genealogies, as they 'show' that sovereignty is bestowed upon the ruling dynasty by God. Any references to the origins and Mundang identity of the chief of Kaele would of course reveal his non-Muslim and non-Fulbe background, and thus defeat the purpose of the poem. However, the song clearly shows the composer's conviction that a canton chief like Kakiang is largely a colonial creation. Kakiang is, for instance, called the "White man of Kaele in "France"'.

The ambivalent status of the two chiefs among Fulbe aristocratic circles is also clear from the fact that they did not succeed to marry a daughter of a Fulbe laamiido or high court notable. At the Fulbe courts the rule of ethnic endogamy was strictly observed: Zuah and Kakiang were not considered suitable sons-in-law, and had to agree to marrying daughters of Fulbe commoners.

The Mundang chiefs's responsiveness to the wider political conjuncture is also illustrated by the fact that the Fulbe variant of Islam, as well as Fulbe power symbolism, have gradually faded into the background in the public image making of the chiefs of Lara and Kaele, after the dominance of the Northern power bloc on the national and provincial levels had considerably diminished in the first half of the 1980s. I mention just a few examples. Chief Kakiang has abandoned his earlier habit to dress like a 'traditional' Fulbe ruler, with the face almost completely covered. He has recently given ethnic (i.e. Mundang) names to several of his younger sons who had only received a Muslim name at their birth, in connection with their participation in the local initiation ceremony (kanne). The present chief of Lara, Ahmadu (1979 - ) is less strict a Muslim than his father was: he publicly consumes alcohol, and does not obstruct the performance of the ancestral masques in any way. It seems that both chiefs are more and more in favour of a tolerant kind of Islam. This renewed interest in Mundang local culture has to do with the political weakening of the Fulbe after the failed putsch in 1984: since then Muslim hegemony has completely disappeared in the context of the ruling party. This has become very manifest at the multi-party elections in 1992: most Muslims in North Cameroon voted for the opposing UNDP (Union Nationale pour la Démocratie et le Progrès), whereas the majority of the non-Muslim population as well as Muslim chiefs like chief Kakiang voted for the ruling RDPC 
or the MDR (Movement pour la Défense de la République)(which is closely allied to the RDPC).

The two rulers illustrate the emergence of a new intermediate status category that does not fit the familiar dichotomy between Pullo and Pagan. These islamised non-Fulbe are called juulbe in Fulfulde, which simply means 'those who pray'. As we have seen, the prevailing Fulbe attitude toward these chiefs has been somewhere in between acceptance and non-acceptance. This ambivalence was brought about by the fact that their change of religious identity did not go together with an ethnic identity change; their Mundang-hood has never been at stake. As the representative of his ethnic group, chief Kakiang could not cross the ethnic boundary and pass into Fulbe-hood. Would he have done so, he would have lost his political legitimacy as the spokesman for 'his people' , and thus become unfit to represent them.

\section{Diffusion of Islam}

In the above we have seen that the two Mundang chiefs had to take account of the demands of their Fulbe patrons in the ruling party in order to start off a modern political career. This has resulted in a blurring of the differences between the Mundang chiefdoms and the Fulbe lamidates. One would expect that this accommodation to the wider Fulbe polity would cause frictions between the chiefs and the leaders of the clans in local society, as these elders have a strong foothold in chiefs's affairs. The remarkable thing is that they have hardly voiced any protests. Some tension arose, which however did not escalate into an open conflict.

Let us look at the reactions of the common people with regard to chiefly efforts to encourage conversion to Islam (15). In this field one would expect conflicts to arise. Kakiang's and Zuah's attachment to their Fulbe patrons in the U(N)C party is clear from their holier-than-thou attitude with regard to Islam. However, islamisation is quite a step, as Islam has been a central ethnic boundary marker, which has separated the Mundang from the Fulbe for more than a century and a half. Many Mundang still regard Islam as the religion of the old enemy, and remain averse.

Chief Zuah tried to promote Islam in the 1950s according to a well-tried Islamic conversion strategy: he invited Qur'anic scholars to come preaching and teaching, and distributed 'rosaries decorated with illustrations of Mecca' to the heads of 
villages and wards under his jurisdiction (16). His attempts remained largely in vain.

The chief of Kaele exerted some pressure upon people to adopt Islam in the $1960 \mathrm{~s}$ and 1970s, but again only within the limits of his personal network of clients, i.e. members of his palace, courtiers, and village and ward heads. His wives and children and the palace servants converted, but only a minority of the court notables gave in. His success in convincing his notables in the chiefdom administration can be deducted from the following table, which shows the growing percentage of Muslim ward heads over the years in the urban centre of Kakiang's chiefdom, the township of Kaele.

$\begin{array}{lcccc} & 1960 & \underline{1972} & \underline{1982} & \underline{1990} \\ \text { Local religion } & 79 & 56 & 30 & 21 \\ \text { Christianity } & 7 & 4 & 15 & 21 \\ \text { Islam } & 7 & 36 & 52 & 58\end{array}$

Table 1. Religious identity of ward heads in Kaele town in different years (in \%) (17)

These percentages are not typical for the canton as a whole. Islamic influence remained largely limited to this township. This urban focus is in line with the general pattern of diffusion of Islam in North Cameroon (and West Africa as a whole). Islam was especially promoted in the domain of urban public symbols. In order to grant the town a Muslim image, Islamic - i.e. Fulbe or Hausa - names were given to newly created wards. The influence of Islam is also manifest in the prohibition to sell alcohol and pork at the weekly market, which came into force in the 1960s. Chief Kakiang also ordered at his costs the construction of a nice mosque along the town's main entrance road. Furthermore, he appointed an imam, and a Muslim judge (Arab. qadhi, Fulfulde: alkali); he surrounded himself with a group of Qur'anic teachers as general advisers in Muslim-related issues. Moreover, he stimulated the establishment of Qur'anic schools in his canton; around 1980, there were about twenty of these schools in Kaele town alone) (18). 
The rural zones of the two chiefdoms largely escaped islamisation. In the 1960s, rural chiefs and male elders without any party-career ambitions were usually left alone as far as their religious affiliation was concerned. A formal adherence to the party was considered to be enough. The majority of the common people was hardly affected by the new political developments nor involved in the resource distribution taking place within the party patronage system. They opposed conversion, as it was not in their interest. Furthermore, a general dislike of Islam as the religion of the Fulbe was still so widespread among the people that Zuah and Kakiang did not start using their Muslim names in public until well into the 1960s.

In the first half of the 1970s the pressure upon the local population to convert increased considerably. Many village heads converted and with each of them dozens of villagers. In the bigger villages small Muslim communities sprang up. However, it were not the chiefs who were the prime initiators of this pressure, but the Muslim sub-prefect at the time. This official invited Qur'anic scholars from Fulbe regions to come over and preach; he pressed local chiefs to convert (if they had not done so already), and to convince their followers to do the same. The chief of Kaele supported him in this effort by accompanying him during his promotion tours in the area, at which occasion the sub-prefect distributed money and clothes to the village and ward heads. Kakiang advised the people to embrace Islam at his public speeches, but he did not force them. In the years 1973-1975 the third Mundang chief (the one of Boboyo), the two Giziga chiefs (of Midjivin and Moutouroua), and one of the four Tupuri chiefs in the Kaele district converted to Islam. These conversions produced a wave of islamisation within the networks of personal clients of these chiefs. For example, two months after the conversion of its chiefs, 570 people in the village of Midjivin and 168 in the village of Boboyo embraced Islam (19).

After 1975 the pressure dissipated. The results were rather meagre. Islam had penetrated into the networks of personal dependence relations of the chiefdom structure, but only to a limited extent. The township of Kaele, where the progress of Islam was most notable, can serve again as an example. Table 1 shows that almost half of the ward heads were able to withstand the pressure to convert to Islam, and some even converted to Christianity. Even within the immediate family circles of the chiefs not everybody converted to Islam: only three of the seven brothers of Kakiang have become Muslims, and a junior brother of chief Zuah of Lara even became an active promoter of Christianity as a catechist.

The common population was hardly touched by Islam. The Christian missions proved to be much more effective in making converts among young men and 
among women, in spite of all kinds of tacit obstruction from the side of the regional administration and the chiefs. In Lara, for example, the Catholic Mission was the dominant social force in the 1970s. This was admitted in an administrative report written by the Muslim sub-prefect of the time, as the following quotation shows (in my translation)(20):

'The situation of Lara needs to be re-examined. This locality has completely come under the influence of private initiative. The presence of the Catholic mission since more than 20 years, and its social investments (a primary school with a complete range of classes, and a dispensary) have caused the local people to depend in practice much more on this church than on the state.'

The situation in Kaele town is also illustrative: most recently islamised ward heads commanded a predominantly non-Muslim population that was in a process of becoming Christian. In 1972 this was true for $56 \%$ of the Muslim ward heads, and in 1982 of even $71 \%$. Furthermore, the few conversions that actually took place, were largely nominal. Most converts remained integrated in the clan structure of the ethnic group, continued to actively participate in the cults of the land and of the ancestors, and continued to consume millet beer and pork.

The social significance of islamisation was not so much that of a religious identity change of the people concerned, but a conformist attitude towards the dominant political ideology of the time, which happened to be Islam. This is also clear from the public speeches of chief Kakiang, in which he gave the impression that a conversion would be an act of loyalty to president Ahidjo. The easily performed Islamic conversion ritual should thus not be seen as an indicator of religious identity change, but rather as an expression of political conformity. Given the political nature of conversion, it is no surprise that the popularity of Islam has dwindled after the political change of power in Cameroon after the failed coup in 1984. Since Muslim hegemony over the regional state-party apparatus has come to an end, a wave of de-islamisation has taken place in the Kaele region. In most Mundang villages there are hardly any Muslims any more (21).

The conversion pattern in local Mundang society shows that Zuah and Kakiang have hardly managed to spread Islam among the populations they ruled, despite the support from regional administrators for some time. The pattern of islamisation neatly corresponds to a structural feature of Mundang society: a distinction between the kingdom and clan levels. The limited appeal of Islam can only be understood if we take account of this distinction. 


\section{The king versus the elders}

The chiefdom and clan levels are two distinct domains of male power, which cannot be reduced to each other (22). I will present a simplified sketch of this dual structure, by making use of Alfred Adler's analyses of the dominant cosmology of the pre-colonial Mundang chiefdom of Lere in Chad (23). The simplification consists in the fact that I take the differences in organization and ritual between the Mundang of Lere and the northern Mundang to be negligible. This is a sound procedure, because the local political culture in the Kaele region has been largely modelled on the Lere kingdom, so that differences only exist in details.

The clans are gerontocratically structured, although not to such an absolute extent as the dominant male ideology wants us to believe. An elite of male clan elders monopolizes most positions of power and authority. The clans are patrilineal, and their members live scattered over several villages. They are linked to each other by ties of marriage - each clan is exogamous - and until well into this century by blood feud. The elders of the autochthonous clan pockets in a locality are the guardians of a land cult (which takes care of the ritual aspects of the use of land lest it loses its fertility), and an ancestral cult (which is the institutional setting for the male initiation ceremony and for the funeral ceremonies of high-ranking elders).

The clan pockets of one or several villages are integrated into the chiefdom structure. In terms of its mode of production, its territorial organization, and its ritual domain, the kingdom represents a distinct structural domain complementary to that of the clans. The various cosmological mechanisms through which the two domains are integrated in Mundang society manifest the power of the clan elders with regard to the king:

Firstly, the clan elders are the kingmakers. This small elite forms a powerful council of advisers, that is responsible for the most secret royal rites of passage, i.e. the king's coronation and his funeral. During an interregnum - which in principle would last about a year - this council would replace the king. At the yearly harvest festival the authority of the elders as kingmakers is still expressed and reaffirmed.

Secondly, the clan elders are the 'bride-givers' to the chief, if one can say so, and as such they exert an authority as fathers-in-law. Contrary to marriages in the clan domain, the chief marries women without any compensation to the families. There is a local proverb that says: 'marrying a woman is like buying a camel' (pa bang 
ngwee a na pa lee njonjong), which means that the debt of a son-in-law to his parents-in-law can never be completely discharged. Hence, the king is in a never-ending debt relation to the category of clan elders as a whole.

Thirdly, the elders of the autochthonous clans are the 'owners of the land'. They are the guardians of the land cult, whereas the chief is mythically presented as a stranger, who has been invited to come and rule. This cosmological opposition between autochthonous versus allochthonous is brought out in social life in the form of an avoidance relation between the king and the ritual leader of the land cult, the pasyingri (litt. 'master of the spirits'), who represents a lethal force to the former. This type of gerontocratic authority is symbolised by secret regalia. These represent the (re)productive potential of the land and ultimately belong to the local clans pockets. The regalia are periodically 'purified' by the most important 'master of the land' (paseri, or piliang as he is called in the Kaele region). It is the first wife of the king who stores them in her house.

Fourthly, several clans elders claim complementary authority, due to a particular role within the kingdom cosmology. The chief of Kaele, for example, stands in a perpetual kinship relation to the Toonri clan, whose elders he has to respect as his senior brothers. Furthermore, the Tekabbe clan elders are responsible for all royal blood sacrifices, and the Lah Tegeere clan elders function as the 'medicine men' of the chief.

The king depends on these gifts in order to rule legitimately. He needs a territory with subjects who respect his jurisdiction; he needs a multitude of wives, to grant him children and to produce the material richness required for periodic sacrifices and ceremonial redistributions; he needs the secret regalia to meet his most important responsibility, to make rain; and he needs 'medicines' to remain healthy; and sacrificial specialists to meet his ritual obligations. The royal 'work' - in practice it is realised by an extreme passivity, an abstention of any productive task - is essentially sacrificial in nature. The chief is not activity involved in sacrificial blood shedding: he delivers the animals to be slaughtered, but the actual killing in Kaele is done by a Tekabbe clan elder, who exposes himself, by doing so, to the lethal force of the regalia. However, in essence it is the chief himself who is the sacrifice. This secret points to the presence of a notion of ritual regicide in the Mundang cosmology. This 'work' goes together with a number of prohibitions: a chief should neither eat or drink, nor touch the earth, carry out physical work, and least of all die - at least not in public.

The interdependence between the chief and the clans is periodically celebrated in the rituals of the royal cult, in the form of sacrificial meals at the harvest festival 
and the rain festival. The commensality surrounding these meals symbolizes prosperity and social order. The dish consists of millet (which represents the clan level) and meat (which represents the kingdom level). It is produced by members of the royal compound, and the whole village population is invited to participate in this ritual consumption.

Many elements of this cosmology are still discernible in the present politico-ritual system of the chiefdoms of Kaele and Lara. However, the system as such is no longer fully operational, due to the impact of colonial rule. In the 1920 s the French administration imposed a political reform of the Mundang kingdoms. Several of them were put together to form a small number of cantons. The introduction of several features of the Fulbe lamidates by French colonial officers considerably enhanced the power of the Mundang kings. The council of clan elders was transformed into an advisory institute whose members were partly appointed by the chief. It was henceforth called faada, which means 'court' in Fulfulde. The 'war chief' (kaygamma) became the official replacement of the chief during an interregnum (which was considerably shortened in the process). A territorial hierarchy of village and ward heads, nominated by the chief, was imposed upon the clan structure. Finally, the chief's rights to distribute land increased considerably, at the expense of the leaders of the land cult. Since then, the authority of the clan elders as kingmakers and 'owners of the land' has seriously declined, and the performance of public rituals has steadily eroded. However, the power and authority of the elders are still considerable, as we shall see.

\section{Ritual duties of the king}

Islamisation neatly reflects the dualistic nature of local Mundang society: it has remained restricted to the chiefdom level, and has hardly trickled down to the clan level. Given this situation, one would expect some tension to arise between the Muslim chief and the clan elders at the ritual ceremonies. However, the two Muslim chiefs have generally managed to reconcile their efforts to be 'good Muslims' with their Pagan responsibilities of a ritual and redistributive nature.

The Muslim chiefs have continued offering food and clothing to the clan elders who are members of the advisory council, as well as offering food to all inhabitants at the yearly festivals. The islamisation of the royal compound caused a serious problem though. According to the new norms the women were no longer allowed to engage in several productive activities: the work on the fields and the preparation of millet beer. The chief's spouses lost their fields, were no longer 
allowed to work the land, and had difficulty in leaving the palace for the streets (although it was accepted in the evening twilight when one is less conspicuous). A twofold solution was found for this loss of female working power. Part of the female tasks were contracted out to non-Muslim women from outside the palace; and the chiefs managed to extract more forced labour on their fields from the population, due to their increased power over land tenure issues.

As we have seen the role of the chief in ritual matters is largely a passive one, since the actual sacrificing is done by a ritual specialist of one of the clans. As far as I know, the chief of Kaele has never refused to provide cattle for sacrificial purposes. The king's rain-making responsibilities and the masquerade of the ancestor cult are hemmed in secrecy, and thus do not openly contradict with the chief's public image of a strict Muslim. It is easy for him to dissimulate his involvement in these 'traditional issues', for example by emphasising that these are not the business of outsiders (like myself) (24). His Muslim identity proves to be situational: it is stressed in the interaction patterns with the wider society, and far less relevant in the intra-local interaction patterns between king and commoners. The shroud of secrecy which is woven around several facets of local religion to outsiders, is very functional in this respect.

Only in those rare cases where the chief's active and public ritual participation was required, some tension arose. In the mid-1960s chief Kakiang had problems with a purificatory libation ritual during the zah beleere ceremony, which is part of the land cult and is presided over by the above-mentioned piliang (25). He refused to be poured over with a mixture of white millet flower and water (sumbii) at some point in the ritual process. This brought him into conflict with the elite of clan elders in the kingdom: they threatened him to withdraw the war drum (damme) from his palace as a token that they would no longer accept him as their king. The conflict was, however, settled without escalation. It was decided that the elders would no longer insist on the libation of the king, whereas Kakiang promised to be present at the ceremony, and to refrain from sabotaging the performance of rituals and festivals.

The power of the king to obstruct ritual performances is considerable: it is the king who is responsible - after an obligatory consultation of several diviners using stones (pakendang) - for fixing and announcing the dates of the yearly festivals; and he guards the funeral drum (yung wuli), without which no ritual of the ancestor cult can be held. Chief Zuah of Lara has tried to minimise the performance of the ancestral masques at the festivals and at the funeral dances, and their roaming about in the chiefly village of Lara during the last month of the Mundang year cycle (fing deblii), but he has never imposed a general prohibition. 


\section{Conclusions}

My hypothesis that the chiefs would encounter a considerable amount of resistance from the side of the clan elders as soon as the former would adapt themselves to the Fulbe-dominated outside world, is not confirmed. The two chiefs developed into rather orthodox Muslims in the first two decades after independence, by contrast to the syncretic tendencies in the beliefs and practices which have developed in many pre-colonial states in West Africa. The clan elders largely remained silent, as we have seen.

Two explanations, one exogenous and the other endogenous, are suggested by the data which have been presented in my argument. Firstly, the process of state incorporation that accelerated strongly in the first half of this century, is relevant in this respect. The chiefs could distance themselves somewhat from the sacred and ritual facets of their authority, due to the considerable change in the nature of chiefly authority during the colonial period. The increase in administrative and political tasks of the kings (in their role of canton chiefs) meant that the legitimation of chiefly authority started to rely more upon the relation of the chiefs with the colonial state than upon their relation with the population. The chiefs's increasing dependence on regional administrators explains their growing concern to be accepted as legitimate authorities by these bureaucrats. We have seen that the chiefs's new tasks and responsibilities, imposed by the Europeans, were partly modelled on the pre-colonial power structure of the Fulbe lamidates. In North Cameroon in the 1960s and 1970s, the post-colonial state came to be dominated by Muslims, and therefore it is quite logical that several Mundang chiefs converted to Islam, and emphasised a kind of Fulbe laamiido image in their official presentation at, for example, the parades at the national Cameroon feast days. After the Muslim dominance faded away, they have done much less so. This historical variability, corresponding to state developments at the regional and national level, is an indication that the contemporary power position of the Mundang chiefs depends much more on their legitimation with regard to the regional state elite than on their popular authority, which is anchored in local Mundang cosmology.

This old cosmology, institutionalised in a court cult, a land cult, and an ancestral cult, has eroded over the past 50 years. This is due to the growing impact of Christianity, and of cotton and dry season millet (muskwari) cultivation. Christianised Mundang tend to withdraw from the chiefly public rituals in so far as these are regarded to be incompatible with the doctrines of this world religion, 
notably in the domain of sacrifice. The ritual management of the land has weakened considerably, and consequently the impact of the leaders of the land cult, because the growth cycle of the new crops does not match with the Mundang ritual calendar. As a result, the clan elders have lost much of their power and influence over the king. This partly explains why these representatives of the population could not prevent Zuah and Kakiang from converting to Islam, although they probably would have wanted to, given the anti-Fulbe sentiments that were prevailing in the 1950s and 1960s.

The loss of power of the clan elders, however, only partly explains why they have not voiced any serious protests. I think an endogenous explanation, paying attention to local cosmology, might provide the rest of the answer.

In the foregoing I have stressed that the active ritual involvement of the chiefs in the major rituals has been so limited and/or secret that it has been easily reconcilable with a public Muslim identity. What is more important, however, is that the clan elders have never really objected to the islamisation of the kings, to their adoption of a 'modern' religious identity which has significance in the wider world, as long as the kings would fulfil their ritual and redistributive responsibilities. Personal convictions and doctrine issues are of no relevance in this matter. Evidently, the extrovert, accommodating behaviour of the chiefs has been quite legitimate in the eyes of the common population. This points to a functional division in local society. The king is outside the clan structure, and thus not hampered by the rigorous norms which guide the interaction between kinsmen. This is in line with the cosmological image of the king as an invited stranger, who has come from elsewhere. Therefore, he has considerable freedom of manoeuvre to adapt himself to the exigencies of the outer world.

The kingdom structure finds its ultimate legitimation in local cosmology in a twofold process: an appropriation, and subsequent transformation of potentially negative outside forces (which threaten to destroy the clan structure) into positive ones, which guarantee the survival of the clan order in an ever-changing world. The regalia symbolize this process. In short, the chiefdom's raison d'être is to deal with the outside world, protect the clans from its negative influences, or, if possible, turn them into positive ones. Thus, the Mundang kingdom has functioned as a 'cultural brokerage-mechanism', as a progressive mechanism for the incorporation of outside cultural traits, derived from other ethnic groups. This process-like feature is anchored in the old cosmology of the Mundang, which is intimately linked to the annual cycle of millet agriculture. The Mundang chiefs have a female-like, inclusive aspect, which is most clear in their rain-making quality. They are not believed to generate rain, but to see to it that it falls at the 
right time and at the right spot. The rain is an outside force, as the clouds come from far away. The chiefs are held responsible for a transformation: it is their task to turn the potentially harmful force that rain is, into a beneficial one. They see to it that it fecundates the land - which is the domain of the clans - so that the millet seeds can come alive and produce a good harvest.

This feature is the 'motor' behind the political behaviour of the Mundang rulers. The Fulbe have been the major outside threat to the Mundang since the early 19th century. The Mundang polities have a history of accommodation to these powerful enemies: the kings have adopted many outward characteristics of the Fulbe status system in order to become acceptable as brokers to the Fulbe overlords, and in the late 19th century they had even started to imitate the superior warfare system of the Fulbe, which was based on a cavalry. At that time this selective accommodation was part of a defensive strategy vis-à-vis the Fulbe. The European colonial power subscribed to the existing prestige system of authority, at the top of which figured the laamiibe, and introduced several elements of the Fulbe lamidates into the Mundang chieftaincies. Therefore, the Mundang chiefs continued to regard these Fulbe rulers as the prime reference figures after they had submitted to the superior power of the Europeans. This outward orientation and cameleon-like character of the Mundang kingdom is not a deviation from its 'traditional' function, but the very essence of it. By adopting Islam and other Fulbe characteristics, the chiefs just did what they were legitimately supposed to do. The kingdom is a kind of 'window', so that it is no surprise that it is especially at this level that we find a blurring of ethnic boundaries. The mimetic behaviour is legitimate, as long as it functions as a buffer to maintain the relative autonomy of the introvert clan structure of Mundang society.

This interpretation provides an answer as to why this adaptive behaviour did not cause more resentment among the population than it actually did. Problems only arose when the king threatened to distance himself from his ritual duties, thus endangering the cosmological framework of the kingdom-clan interaction pattern. The chief's participation in the rituals is a guarantee that the extrovert behaviour of the chiefs is ultimately transformed into the well-being of the Mundang population as a whole.

This faculty of the Mundang kingdom to incorporate outside influences as a mechanism of adaptation does not seem to constitute a general characteristic of African states. If a Mundang peculiarity, it might provide part of the answer to a remarkable contradiction: Mundang society have generally proved to be very responsive to outside influences, while at the same time its members have preserved a rather strong sense of ethnic identity. 
Let us now analyze the dealings of the chiefs with the outside world at a higher level. The conversion to Islam of Zuah and Kakiang is related to the emergence of a Northern power bloc, since this regional identity has become closely associated with Islam. This world religion has emerged as the prime ethnic marker of a Northern identity: the opposition between Northerners and Southerners has primarily been perceived as a difference between Islam and Christianity/Paganism. In that sense it would be more accurate to speak of a 'regionalisation' of Islam instead of an 'ethnicisation'. Since independence, tribalism and regionalism have been officially discouraged. However, both phenomena have received powerful reinforcement through de facto practices of governance: like in the colonial period, state resources and nominations continued to be allocated largely along ethnic and regional lines. The emergence of the Northern power bloc should be seen in this context.

The remarkable thing to note is that this trend toward religious homogeneity has gone hand in hand with a maintenance of the pre-existing ethnic heterogeneity. The ethnic identity of autochthonous ethnic groups like the Mundang has been explicitly recognised by the post-colonial regime. They were not suppressed but rather included in the new political order of the one-party state.

It was only then that Islam could begin to penetrate the non-Fulbe societies of North Cameroon, instead of merely detaching individual members from the clan domain and incorporating them into Fulbe society. In other words, in the context of the post-colonial state, islamisation is no longer so inextricably associated with ethnic identity change, with assimilation to the Fulbe, as it was in the pre-colonial and colonial days.

Although Islam in North Cameroon is still heavily coloured by Fulbe culture, a new development has set in which tends to transform it into a poly-ethnic religion in this region. Islam has started to dissociate itself from one ethnic group, and gradually gives rise to a poly-ethnic community. This is evidenced by the emergence of a new category of believers, the non-Fulbe Muslims, which are called juulbe. Indigenous chiefs like Zuah and Kakiang have been the trend-setters. At first sight the adaptive behaviour of the Mundang chiefs seems to underscore the Pullo-Pagan distinction, as it presupposes an acknowledgement of the cultural superiority of the Fulbe; in the short run this is true. But in the long run this behaviour undermines this ethnic distinction, because it is an expression of the actual and desired trend toward more egalitarian ethnic relations in the area. It is yet to early to determine what kind of religious changes will eventually result, but I guess that the trend toward 'ethnicisation' which existed so strongly until recently, will rapidly subside. 


\section{Notes}

1. Cohen 1969.

2. See Nicolas, 1978: 347-377; and 1981: 170-180.

3. Schultz 1979, 1980, 1984.

4. 'Pagan' is not a neutral (and then dubious) sociological category, but an implied complementary religious category in both Islam and Christianity, referring to those elements of the local religions that must be deemed incompatible with these world religions, i.e. the cult of ancestors and spirits other than the Supreme Being (Peel, 1978: 448). Therefore I retain the term 'Pagan' throughout my argument as a rendering of an aspect of the participants's religious outlook. In North Cameroon, the link between Islam and cultural superiority is based on literacy: an old stereotype goes that Muslims can read and write, whereas Pagans cannot.

5. My research in North Cameroon has been financed by the African Studies Centre in Leiden (Netherlands). I like to thank Wim van Binsbergen, Peter Geschiere, José van Santen, and Rob Buijtenhuijs for their useful comments on an earlier version of this article.

6. This topic has been extensively studied by the French ethnographer Alfred Adler for the Mundang kingdom of Lere. See notably Adler 1969, 1978, 1981, 1982, 1987.

7. This general pattern is described in two articles in a recent study on ethnicity, for example: Devisse 1989 and Kouanda 1989; see also Nicolas 1981: 54-63.

8. The pronounced ethnic-religious dichotomy between the Fulbe and the indigenous ethnic groups in the region, which goes back to the last century, can still be found in many recent academic studies on North Cameroon society. The finest example is Boutrais et al. 1984.

9. See e.g. Blanckmeister \& Heine 1983. This is not to say that Islam is completely politicised in North Cameroon. On the contrary, religious beliefs and practices of the common Muslim population in the region are remarkably little imbued with political matters (compared to northern Nigeria).

10. See Zoua 1982: 67.

11. Lacroix 1965: 168-177.

12. Until 1975 this supreme body of the party was called the Political Bureau.

13. See Rothchild 1986: 72.

14. Lacroix 1965: 30-31.

15. See also Schilder 1991.

16. Source: Mazarguil 1955.

17. Source: standardised interviews with all 26 ward heads in Kaele town in 1990.

18. Zoua 1982: 61 .

19. Zoua 1982: 74-76.

20. Source: Sadou 1977: 8.

21. Unfortunately, I do not have information about conversion trends among the female half of the Mundang population. I have the impression that conversion to Islam was primarily a male affair, because of its political nature. The men maintain that women's behaviour in matters of religious change conform to the dominant norm that 'a woman should follow her husband'. It should not be excluded that women follow their own conversion strategies, although the virtual absence of religiously heterogeneous households does not corroborate this hypothesis.

22. These are not the only power domains in contemporary Mundang society. Other ones are, for instance, the local market, the body of governmental services, and the more 'hidden' exercise of power by women. 


\section{See note 6.}

24. I must say that I sympathize with this viewpoint. The Western-scientific 'need' to unmask ritual secrets can be very destructive in the African context: secrecy and its associated rumours are essential for the ritual efficacy. Everybody talks about the secret things, but few know the ins and outs of the matter, and those who do keep silent. It is quite probable that as soon as these rituals are stripped of their secrecy something very trivial remains, which lacks any cultural meaning.

25. The zah beleere ceremony is typical for the northern Mundang in the Kaele region; it is not found in the Lere region.

\section{References}

ADLER, Alfred (1969). 'Essai sur la signification des relations de dépendance personnelle dans l'ancien système politique des Mundan du Tchad', in: Cahiers d'Etudes Africaines, 9, 35 : 141-160.

ADLER, Alfred (1978). 'Le pouvoir et l'interdit: aspects de la royauté sacrée chez les Moundang du Tchad', in: Systèmes de signes: textes réunis en hommage à Germaine Dieterlen, Paris, Hermann: 25-40.

ADLER, Alfred (1981). 'Le royaume moundang de Léré au XIXe siècle', in: Cl. Tardits (ed.), Contribution de la recherche ethnologique à l'histoire des civilisations du Cameroun, Paris, CNRS: 101-112.

ADLER, Alfred (1982). La mort est le masque du roi: la royauté sacrée des Moundang du Tchad, Paris, Payot.

ADLER, Alfred (1987). 'Tradition orale et historicité chez les Moundang du Tchad. La généalogie des rois de Léré: structure d'un texte', in: Poikilia (études offertes à Jean-Pierre Vernant), Paris, EHESS: 49-67.

BLANCKMEISTER, B. \& P. HEINE (1983). 'Ethnizität und Islam in Nordkamerun', in: Afrika Spektrum, 18, 2: 171-175.

BOUTRAIS,J., J. BOULET, A. BEAUVILAIN et al. (1984). Le Nord du Cameroun: des hommes, une région, Paris, ORSTOM.

CHRÉTIEN, J.-P., \& G. PRUNIER, réd., 1989, Les etnies ont une histoire, Paris: Karthala/Agence de Coopération Culturel et Technique (ACCT).

COHEN, A. (1969). Custom and politics in urban Africa: a study of Hausa migrants in Yoruba towns, Berkeley, University of California Press.

DEVISSE, Jean (1989). 'Islam et ethnies en Afrique', in: J.-P. Chrétien \& G. Prunier (eds.), Les ethnies ont une histoire, Paris, Karthala: 103-115.

KOUANDA, Assimi (1989). 'La religion musulmane: facteur d'intégration ou d'identification ethnique (le cas des Yarse du Burkina Faso)', in: J.-P. Chrétien \& G. Prunier (eds.), Les ethnies ont une histoire, Paris, Karthala: 125-134.

LACROIX, Pierre-Francis (1965). Poésie peule de l'Adamawa, Paris, Juliard.

MAZARGUIL, J. (subdivisional officer of Kaele) (1955). Rapport politique mensuel du ler Août 1955 au 31 Août 1955 (Unclassified file in the archives of the Sub-Prefecture of Kaele)

NICOLAS, Guy (1978). 'L'enracinement ethnique de l'Islam au sud du Sahara: étude comparée', in: Cahiers d'Etudes Africaines, 18, 71: 347-377.

NICOLAS, Guy (1981). Dynamique de l'Islam au sud du Sahara, Paris, Publications Orientalistes de France. 
PEEL, J.D.Y. (1978). 'The Christianization of African society: some possible models', in: Edward Fasholé-Luke, Richard Gray, Adrian Hastings \& Godwin Tasie (eds.), Christianity in independent Africa, London, Rex Collings: 443-454.

ROTHCHILD, D. (1986). 'Hegemonial exchange: an alternative model for managing conflict in middle Africa', in: Dennis Thompson \& Dov Ronen (eds.), Ethnicity, politics and development, Boulder.

SADOU Abbo Ibrahima (sub-prefect of Kaele) (1977). 'Situation économique et sociale de l'arrondissement de Kaele' (unclassified file in the archives of the Délégation de l'Arrondissement d'Agriculture de Kaélé).

SCHILDER, Kees (1991). 'Etat et islamisation au Nord-Cameroun (1960-1982), in: Politique Africaine, 41: 144-148.

ZOUA, M.L.(1982). Religion traditionnelle, Islam et Christianisme dans la région de Kaélé (1900-1978), (unpublished doctoral thesis), University of Yaounde. 